Send your letters to the editor, British Dental Journal, 64 Wimpole Street, London W1G 8YS or by email to bdj@bda.org

Priority will be given to letters less than 500 words long. Letters should be typed. Authors must sign the letter, which may be edited for reasons of space

\section{Patient in pain}

Sir, do we have a duty as members of a healing profession to help people in pain? As a student in the early 1950's I recall being told by an honorary lecturer at my training hospital, that time should be set aside to treat patients in acute pain even, if it involved shortening one's lunch time or forgoing a tea break, as part of our professional duty was to alleviate pain

Having worked in the NHS for 40 years and in private practice for 10 years, I am aware of the pressure of too many patients and insufficient time during a working day.

Recently whilst travelling up to Cumbria I fractured a molar tooth exposing the pulp and within hours it was extremely tender, to both touch and temperature change. On arriving at the hotel I inquired as to the availability of an emergency dentist, was given a list of local practices, some NHS, and two private patients only. The next morning I presented myself at the first of the private practices, explained that I was a retired dentist, that I was in considerable pain, but was informed that the practice only saw their own registered patients, and non registered patients were not seen!

I then tried the second private practice with exactly the same result. Incidentally, both were multiple practices, with empty waiting rooms! I then tried three different NHS practices all with overflowing waiting rooms and the receptionist at the last one, gave me the telephone number of the nearest NHS direct establishment some 15 miles away from Cockermouth. On phoning them, I was told to phone back by $8.30 \mathrm{am}$ the next day and they would try and fit me in. This I did, and the young New Zealand trained dental surgeon examined me and extracted the split lower molar. It concerns me that today's graduates do appear to be unaware of the ethics of a healing profession, and that will lower the public's respect for the healing professions. A patient in pain, successfully treated, more often than not becomes is a good patient, often for "life".

H. Soni

Surrey

doi: 10.1038/sj.bdj.4812243

\section{Dental irrigators}

Sir, I was pleased to read your articles in the GSK Oral Health Report of October 2004, which I thought were useful. You are well aware that periodontal problems have an increasing relevance in modern day society, and I continue to be frustrated by the lack of recommendation of inter-dental irrigation in the prevention of this problem. For many years Oral 'B' manufactured and sold a Water Pik which is an electrical pump with a tank of water and fine nozzle to flush out debris from the interdental spaces. Of relevance to GlaxoSmith Kline and other manufacturers of mouthwashes, the addition of a small amount of mouthwash to the tank of water improves the cleaning and will help to reduce the bacterial content of the interdental spaces. This type of appliance is freely available in the United States, but is difficult to find in the UK. The problem is made worse as periodontists may rightly say that irrigation does not remove plaque, but seem unwilling to accept that it removes much of the debris which causes plaque. Periodontists recommend the use of dental tape on a regular basis, which may well be efficacious but is difficult to use, and therefore not practised conscientiously by a large proportion of the population. The elderly particularly who are losing some of their manual dexterity, find this technique impossible. I understand that in the United States the use of water irrigation with an antiseptic mouthwash is now being promoted for the prevention of periodontal disease, and I am sure this would be a valuable asset in the United Kingdom if promoted properly.

The purpose of my letter is to draw your attention to this issue, and if properly promoted by the British Dental Association in conjunction with the manufacturers of mouthwash, a large benefit to the population in terms of their dental health would be achieved. I personally have used an irrigator for twenty years and would never be without it.

\section{P. T. Blenkinsopp}

Kingston-upon-Thames

doi: 10.1038/sj.bdj.4812244

\section{Audits}

Sir, in the opinion column of BDJ 2004, 197: 517, your predecessor speculates on the effectiveness of Clinical Audit (CA)/Peer Review (PR). His feelings are, I suspect, shared by many, that the benefits are uncertain and that the usefulness of the entire process is at best unquantifiable. He asks if there is anyone able to offer more

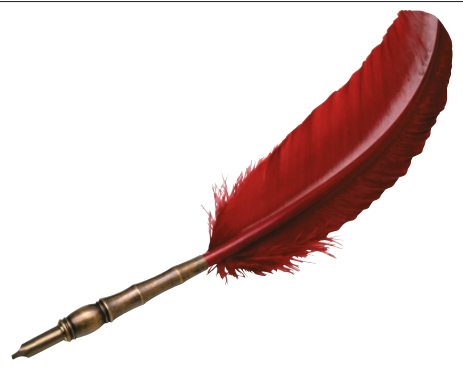

than a guesstimate of the value of the procedure. Southend-on-Sea PCT has made an effort over the last two years to help local practitioners make the process of CA/PR easier and more rewarding.

We two GDPs have worked with and for the PCT over that time and have tried to justify our title as Facilitators by arranging group audits for any and all dentists across the PCT as part of a Modernisation Agency field site programme. So far we have completed a baseline audit of general practice and an audit into antibiotic prescribing, both have produced interesting results. These have then been the subject of post audit peer review sessions allowing discussion of audit results by participants, any changes that need to be made in the light of these results and how these changes may be facilitated.

For example educational needs that manifest as a result of an audit can be fed into the local Deanery postgraduate educational programme. Currently we are analysing data from an audit into periodontal risk management. Many of Southend's dentists will thus soon complete their fifteen hours of required audit with two years to spare. The whole process has been well received, well supported and participants seem to find it more enjoyable as part of a larger group. We expect to publish progress ${ }^{1}$ and results over the course of the next year and hope that others will find these results relevant and interesting. We are happy to share our experience. Anyone interested in repeating the process elsewhere is welcome to enquire. In relation to the original musing of the former editor, we propose to carry out a cost/benefit analysis of the whole procedure, thereby (we hope) demonstrating that this group approach is both more use to the individual dentist and potentially a more cost effective process than the existing GDS system. Any enquiries should be directed to Sarah Costeloe, Southend PCT, Harcourt House, Harcourt Avenue, Southend on Sea, SS2 6HE or email: sarah.costeloe@southendpct.nhs.uk

W. Abbot, P. Cannell

Southend-on-Sea

1. Cannell P. Linking Clinical Audit in General Dental Services to Primary Care Trust Clinical Governance Progress Report of an Approach Used in Southend. Primary Dental Care 2005;12 (1)

doi: $10.1038 /$ sj.bdj.4812245 